УДК 378

DOI: 10.30914/2227-6874-2019-12-118-130

\title{
The role of universities in the development of a safe environment in the context of mass migration
}

\section{V. Rayushkina}

The article is devoted to the problems of preserving the national security of Russia in conditions of mass migration with special attention to educational migration - foreign students. In the first part of the article the author gives a brief overview of the reasons for the growth of mass migration in Russia in general and in the Krasnodar region in particular, denoting the internal and external risks and threats to the national security of the country. In the second part, on the example of a particular University - Kuban State University (KubSU, Krasnodar, Russia) - it analyzes the conditions of adaptation and integration of foreign students into a foreign language culture on the basis of the "dialogue of cultures" as the fundamental factors of developing a safe educational environment, and offers certain approaches and ways of its making. One of the principal approaches to the problem is the so- called "individually identical" approach to each foreign student, based on personal-psychological and formal-personal relations between incoming and accepting parties, which, in turn, helps the dialogue of cultures arise and develop. The author considers the involvement of foreign students to participate in public, social and cultural activities to be special methods of developing a safe educational environment in the University, that embodies the idea to reveal the inner world of person, his/her abilities that leads to a stable balance and harmony of the individual. The author lists several events held at KubSU with the participation of international students as the veracity of this thesis. It is also proposed to introduce other technologies that contribute to the successful dialogue of cultures and, as a result, to ensure a safe environment at the University. In conclusion, the author emphasizes the importance assigned to universities, which are to provide a safe and favorable educational environment for all students, regardless of their country of origin.

Keywords: Russia, risks and threats of mass migration, Krasnodarsky krai, foreign migrants, working migration, multiculturalism, interculturalism, educational migration, Kuban State University, international students, adaptation, public social and cultural integration, foreign cultural environment, safe environment for education, interethnic conflicts, individual approach, and dialogue of cultures.

Notes: this article includes the report of the same name, which was submitted in the form of a presentation at the International Scientific Conference "Non-State Actors and the Security of the Euro-Mediterranean Area Region", organized by the Jean Monnet Network "Peace, War and the World in European Security

(С Раюшкина И. В., 2019 
Challenges (POWERS)" and took place on January 29-31 at the University of Jordan (Center for Strategic studies) in Amman (accordingly Erasmus+ Grant Agreement № 599962-EPP-1-2018-1-RU-EPPJMO-Network).

Acknowledgments: the author expresses sincere appreciation and gratitude to the Project manager at Kuban State University - Elena Morozova, Professor of the Department of Public Policy and Public Administration, for inviting to participate in the project, to Vladimir Petrov, Professor of the Department of Sociology and to Yuri Smertin, Professor of the Department of Regional Studies and Diplomacy of KubSU, as well as to Professor of Sociology Dr. Marshall Botkin (USA) for the advice, recommendations and criticisms given to the author in the process of working on this article.

Citation for an article: Rayushkina I.V. The role of universities in the development of a safe environment in the context of mass migration. West-East. 2019, no. 12 , pp. 118-130. DOI: 10.30914/2227-6874-2019-12-118-130

Nowadays, the problem of mass migration is addressed by many scientists, researchers, experts, specialists and all those who cannot be indifferent to the migration processes taking place in the modern global world. If we talk about Russia, the most acute problem is in the South of the country - in the regions bordering the republics of the North Caucasus. In this regard, the methodological basis of this research includes the work of the authors analyzing geo - and ethnopolitical, socio-economic, integration, demographic, etc. problems related to risks and threats for Russia's national security in the North Caucasus and Krasnodar region. Among the wide variety of works the most interesting seem to be the researches of Aver'yanov V. A., Avksent'ev V. A. and Gritsenko G. D., Baranov A. V., Demina A. V., Kasyanov V. V. and Shapovalov S. N., including Apazheva S. S., Mamsirov A. K. and Tsoloev T. C., Kashnitsky I. S., Mkrtchyan N. V. and Leshukov O. V., as well as some foreign researchers, including: Gimpelson V. and Kapeliushnikov R., Dustmann C., Schonberg U. and Stuhler J., Dustmann C., Schonberg U. and Stuhler J., etc.

\section{Mass migration: risks and threats}

Russia is a multinational country, where according to statistics there are more than 200 nationalities, $80 \%$ of which are representatives of Russian and Slavic peoples. By 2050, according to the Institute of National Strategy of the Russian Federation, half of the Russian population may be represented by migrants, mostly from Central Asia. In 2018, 16.5 million foreign citizens ("illegal immigrants" not included) were officially registered. Further, statistics indicate that the highest number have immigrated from Uzbekistan, Tajikistan and 
Ukraine $^{1}$. The main reason for the mass migration to Russia is to look for better life for themselves and their families. The reasons cited were:

- Personal and family safety;

- Access to medical care;

- Good quality education;

- Work and livelihood;

- Housing or the opportunity to buy real estate;

- Food needs ${ }^{2}$.

Despite several restrictive measures established by the Government of the Russian Federation, the influx of migrants, mainly workers, into the country is growing $^{3}$. In this connection, it is believed that there are both internal risks and external threats to the national security of the country.

In the Report of the Institute of National Strategy of the Russian Federation, we find a definition of the concepts "internal risks" and "external threats". It says, that the internal risks largely include the demographic factor - the replacement of the native-born Slavic population by migrants of different ethnic groups, who, following exclusively their own ethnic traditions, are not going to assimilate into the Russian-speaking culture. Well-organized, highly mobile and closed to external communication, communities of migrants can be a danger not only for the local population, but also for the existence of Russia's cultural and national identity in the future. However, as known, this phenomenon is happening in Central and Western Europe, where the policy of multiculturalism (group identity and tolerance) has proven to be detrimental and has not justified itself. The danger also lies in the fact that promoting negative Islamic principles among migrants, many of whom are uneducated and lack an understanding of tolerance and acceptance of others, is being increased. Islamists gather in groups and communities that can garner several hundred people only by phone call and very seriously destabilize the situation in any city or village [7, p. 4].

The external threats primarily include the geopolitical factor - the growth of radical Islamism in Central Asia and the periphery of the territory of Russian influence, as well as the increased social tension in these countries with its possible transfer to Russia. In this context, the large-scale influx of IDPs (internally displaced person) in the Russian Federation is a factor of ethno-political and socio-economic destabilization of the Russian Federation [7, p. 5].

Krasnodarsky krai (Krasnodar region) is no exception and ranks fourth among other regions of the country in the number of foreign migrants. One hundred twenty-four ethnic groups ( $86 \%$ of Russians, $5.5 \%$ of Armenians;

\footnotetext{
${ }^{1}$ URL: https://panzer038.livejournal.com/400555.html

${ }^{2}$ URL: https://migrantvisa.ru/russia/migraciya/statistika

${ }^{3}$ URL: http://government.ru/rugovclassifier/11/events
} 
a much smaller percentage are Ukrainians, Belarusians, Greeks, Adygs, Germans, Tatars, etc. $)^{1}$ inhabit Krasnodar Region or Kuban; it occupies the 3rd place after Moscow and the Moscow region in population. Here these citizens have always lived together in peace because of mutual help and mutual respect. The Slavic population is used to living side-by-side with Armenians and Georgians, Adygs and Tatars, so it is unusual to hear any media reports about any inter-ethnic conflicts. Moreover, the Krasnodar region - the southernmost region of Russia, is agricultural. In other words, it is warm, cozy and plentiful. This is the main reason why migrants come to Kuban not only from other countries, but also from the Northern regions of Russia.

It is difficult to disagree with Averyanov AV, who believes that "... recognizing the failure of the policy of multiculturalism implemented in post-war Europe, the European bureaucracy is not able to offer an alternative model of migration strategy. In the conditions of escalation of the international situation and deepening economic crisis, it is highly probable that further growth of social and political instability in the EU countries with the participation of immigrants and their descendants should be predicted" [1]. Then, regarding foreign migrants, the term "interculturalism" should be introduced. This term implies a "micro-level" approach to the problem of migration, i. e. the focus is on "individual identity". The basis of this approach is to find methods of communication for people of different cultures. If multiculturalism is understood as a request for tolerance and social protectionism, then "interculturalism" is understood to be the need for dialogue and transformation [8].

In our opinion, it is logical to consider such a "dialogue" as a "dialogue of cultures" that easily fits into the sphere of education, which, in turn, can serve as a reliable tool in the formation of a safe educational environment at the university. Then, the priority task of universities is to maintain the viability of such a cultural dialogue, thus ensuring a peaceful, secure present and future.

\section{Education Migration: problems and challenges}

Traditionally, for foreign migrants at the first stage of resettlement, male population dominates. Then the "family reunion" comes. On average, one family, for example, from Tajikistan consists of nine members, from Uzbekistan six members. Most of the migrants working in the Russian Federation are trying to give their children a good education. In Russia, foreigners from the UIS (Union of Independent States) can receive higher education at the expense of budget funds (special quotas) as well as vie tuition fee. It is believed that paid education in Russia is not very expensive (from $\$ 1,000$ per year or more, depending on the field of study and major).

\footnotetext{
${ }^{1}$ URL: https://karatu.ru/narody-krasnodarskogo-kraya
} 
From the total number of foreign students attending Russian universities, which is 240 thousand, $79.2 \%$ are representatives from the countries of UIS. We should note that not all representatives of these countries are children of migrant workers; therefore, it is also relevant to talk about education migration.

Participants of educational migration, as well as labor migration, are people of various ethnic groups with their own mentality, cultural traditions, religion, etc. In this regard, it is necessary to consider the risk factors of various kinds of conflicts, for instance, on religious and/or inter-ethnic grounds, which may have a large-scale implication if this process is not controlled. Thus, as mentioned above, universities have a special responsibility to "establish a dialogue of cultures" in the educational environment.

Experiences and practices of Kuban State University (hereafter referred to KubSU or University) are used as an example, namely, what factors influence the development of a safe educational environment. Let us focus on the two most significant factors: 1) the adaptation of international students to a foreign language culture; 2) the social and cultural integration of international students. Adaptation of international students to a foreign language culture

The Government integration policy should be aimed at specific assistance in the adaptation of foreigners: those who wish to stay in our country for permanent living, and those who come for a short period. This is especially important for the second generation, the children of migrants, who should become full members of society not only according to documents, but also according to their own feelings and according to the social guarantees provided by the country's law. Situations are extremely dangerous when representatives of this second generation cannot identify with their new homeland while they have already lost touch with the old one. They grow up marginalized, without a good education and work in an environment that constantly reminds them that they are "outsiders" [7, p. 6]. Therefore, the role of universities in the arrangement of favorable conditions for the adaptation of international students is extremely important.

There is a widespread opinion that the factors affecting the adaptation of international students involve the following:

- Climate

- Personal-psychological relations

- Pedagogical system

- Interpersonal communication

- Living in international dormitories and the life arrangement.

The notion of having a positive climate factor has already been mentioned so we can miss this issue here.

At Kuban State University, there are more than 800 international students from 63 countries of the world. Personal-psychological relations begin long before the arrival of a foreign student at the University, i.e. from the moment of 
his/her first message of request to the Department of International Affairs (hereinafter DIA). The DIA staff, responsible for admission, visa support and organization of his/her arrival, during quite a long correspondence answer in details all the applicant's questions (sometimes the same questions are answered several times), give the necessary recommendations on training and arrangement of every-day life, talk about the rules of behavior at the University and the dorm, as well as about some Russian cultural traditions. Thus, there are developed some formal-personal relations between the applicant and the host side "with a touch of psychological dominance of the latter", i.e. the "newlyminted" student has a feeling that he/she will not be left alone with any problems if they happen. This is how the dialogue of cultures begins, reassuring the international student that during the entire period of stay at the university, he/she can be sure that his/her possible problems will be treated with special attention. In addition, for all international students, regardless of the length of their stay at the university, there are regular meetings organized with representatives of police, department of migration services, and university management, where students can ask any questions and get comprehensive answers.

Thus, the "individually identical" approach to each international student is one of the most significant factors for his/her successful adaptation.

The pedagogic system is the interaction of various interrelated structural components that are united by one educational goal - development of individuality and personality. The pedagogical system of the traditional educational process consists of seven elements: the purpose of learning, the content of learning, students, teaching staff, teaching methods, means of teaching and training forms ${ }^{1}$.

By and large, the pedagogical systems of higher educational institutions of the UIS, despite the transition of most educational systems to the two-level cycle, remain similar, since they have common roots from the Soviet time. Therefore, there are no big problems in the process of adaptation of international students in the new educational environment. However, it should be noted that not all international students, even if they realize the purpose of their studies, are able to master the content of learning. When this occurs, the teaching staff come to the fore, i.e. professors and their teaching methods. These components of the pedagogical system are especially important at the first stage of students' learning - at the foundation course.

In fact, for international students the foundation course is aimed not only at learning the Russian language and disciplines of the chosen field of study, but it is also the "primary school" of life in Russia. It depends on the skill of the professor's management of intercultural, interpersonal communication with students and

\footnotetext{
${ }^{1}$ Pisareva T.A. General principles of pedagogy: lecture notes // Lecture No. 2, section 8. Pedagogical system. URL: http://www.e-reading.club/book.php?book=103
} 
between them within the group, how successfully the process of adaptation of foreign student will take place. In other words, will it be easy for him/her to accept the conditions of the "new" society, how tolerant he/she will be to other cultures, whether he/she will be able to keep his/her personality. At Kuban State University, the work of the foundation course teaching staff is highly valued, and by the students themselves, who, after graduation, continue to communicate with their "first teacher", often until the completion of their studies, and sometimes even longer. In this case, we can talk about the continuation of the dialogue of cultures.

The arrangement of every-day life of foreign students in international dormitories while developing a safe environment deserves special attention. Namely, living in conditions of residence internationality causes a high probability of various kinds of conflicts between students, most often on everyday issues. In addition, many international students, accustomed to keeping a culture of freedom (for instance, Europeans and Americans) can find it extremely difficult to follow the rules and norms of behavior established for all in the dormitory, especially if these rules and regulations contradict the value system of the country, they came from [6].

KubSU has a great experience in solving such problems - the development of student self-governing bodies (Student Council, Student Trade Union Committee, Volunteer Center, Student Scientific Society, Youth Cultural and Leisure Center, etc.) and the organization of tutoring among senior students. During their training at KubSU, international students become members of student self-governing bodies and can have a direct influence on the resolution of a problem or a particular situation. The tutors assist new students to adapt to the education process, to involve them in extracurricular activities, to help them explore the university world, to break the language barrier, without remaining indifferent to the problems of those who are receiving their help. Often, tutors and international students become good friends for many years, so, the dialogue of cultures continues.

Of course, it is not always possible to avoid conflict situations, and they happen from time to time. The main thing, in our opinion, is not to leave them unnoticed.

\section{Social and Cultural Integration of International Students}

To involve international students in the social and cultural life of the University, city or region is a foundation to develop a safe educational environment. In this field, Kuban State University is distinguished by high activity. The widespread involvement of foreign students to participate in social and cultural mass events, held both at the University and in the city and/or the region, allows them to feel an integral part of the whole, full members of a large family, thereby strengthening their life philosophy. 
Public, social and cultural integration of international students implies purposeful, active, emotional solidarity of all its participants. Involving foreign students to participate in public, social and cultural activities embodies the idea to reveal the inner world of a person, his/her abilities that leads to a stable balance and harmony of the individual. It is hardly possible that self-confident, harmonious personality will become the causative agent for any conflicts.

Foreign students attending Kuban State University, enthusiastically respond to offers to take part in the public, social and cultural life of the university and the city. The most popular events with the participation of international students include the following:

1. Freshmen Day.

2. Festival of National Cultures.

3. Day of Science (including publication of articles);

4. Russian New Year; the Carnival; the Day of Victory;

5. Sports competitions of teams of different nationalities and ethnic groups (friendly football matches between faculties, universities, regions and countries);

6. Competitions in the Russian Language and Literature (including at the city level);

7. "Open Lesson", taught by an international student (without professor's assistant), when he/she presents the classmates his/her country, cultural customs and traditions;

8. Various creative competitions (painting, drawing, sculpture, design, performing arts, etc.);

9. Participation in various clubs of interest;

10. Participation in student self-governing, etc.

At the University, some free services for all, including foreign students, have been established and now they are successfully working. They are: "Legal Clinic" - provides students and employees of KubSU free legal assistance; "Psychological Service" - assists and supports in solving various psychological problems. In addition, there are Internet resources of anti-extremist and antiterrorist content, as well as regular conferences on the prevention of extremism, and much more ${ }^{1}$.

According to the reviews of foreign students attending Kuban State University, in general, Krasnodar is a calm, safe and peaceful city, and the University offers a psychologically favorable climate and decent conditions for learning and education ${ }^{2}$.

\footnotetext{
${ }^{1}$ https://kubsu.ru/ru/node/8312

${ }^{2}$ https://www.kubsu.ru/ru/international/about_us
} 
Kuban State University continues to keep on improving the dialogue of cultures. So, it is planned to do the following:

in the sphere of teaching and curriculum

- to include the course of cross-cultural communication in the curriculum of all faculties;

- to refocus the advanced study of regional history to the values of the national unity of Russia; to do a professional examination of educational and methodological literature, curricula;

- to re-certify teaching staff, sometimes allowing the demonstration of ethnocracy in the teaching of the regional component of the Humanities [4];

in the social and cultural sphere

- to unite the students of all higher education institutions of Krasnodar (15 in total) in the universal celebration of the national days of countries and continents, for instance, "Day of Africa", "Asia Day" or "Days of Culture of the East," etc.

- to work out and public in several languages "Socio-Cultural Handbook" for international students, that may become a reliable assistant in overcoming the difficulties of their adaptation in Russia and the host University;

- for the 100th anniversary of Kuban State University, which will be celebrated in 2020, we have arranged a special program of events with the participation of international students, the University graduates, academic partners, representatives of foreign embassies, etc.

In conclusion, we would like to emphasize once again "the key goal of the Russian Government migration policy is "to create the conditions of adaptation to legal, socio-economic, cultural and other living conditions in the Russian Federation for foreign citizens having difficulties in adaptation due to the peculiarities of their culture and habitual way of life" [8]. The most significant role in this issue is also assigned to Russian universities, which are to provide a safe and favorable educational environment for all students, regardless of their country of origin.

\footnotetext{
Abbreviations:

DIA - Department of International Affairs

EU - European Union

IDP - Internally displaced person

KubSU - Kuban State University

UIS - Union of Independent States

\section{References}

1. Averyanov A.V. Migratsionnye protsessy na Yuge Rossii za poslednie 25 let: dinamika i osnovnye napravleniya [Migration processes in the South of Russia for the last 25 years: dynamics and main directions]. Problemy natsional'noi strategii = Problems of national strategy. Russian Institute for Strategic Studies, 2015, no. 6 (33). Available at https://riss.ru/images/pdf/journal/2015/6/07_pdf (accessed 18.03.2019). (In Russ.). 
2. Avksentiev V.A., Gritsenko G.D. Protivorechivost' etnopoliticheskikh tendentsiy na Severnom Kavkaze: ekspertnye otsenki [Contradictions of ethnopolitical trends in the North Caucasus: expert evaluations]. Gumanitariy Yuga Rossii = Humanitarian of the South of Russia, 2018, no. 3. Available at: https://cyberleninka.ru/article/n/protivorechivost-etnopoliticheskih-tendentsiy-na-severnom-kavkazeekspertnye-otsenki (accessed 02.04.2019). (In Russ.).

3. Apazheva C.C., Mamsirov A.K., Tsoloev T.C. Severnyi Kavkaz: sovremennaya etnopoliticheskaya situatsiya i perspektivy yeye stabilizatsii [North Caucasus: modern ethnopolitical situation and prospects for its stabilization]. Istoriya: fakty $i$ simvoly $=$ History: facts and symbols, 2017, no. 13. Available at: http:/historic-journal.ru/2017/sovremennaya-etnopoliticheskaya-situaciya-na-severnom-kavkaze (accessed 14.04.2019). (In Russ.).

4. Baranov A.V. Etnopoliticheskie protsessy v Krasnodarskom kraye v kontekste geopoliticheskikh transformatsiy [Ethno-political processes in the Krasnodar krai in the context of geopolitical transformations]. Teoriya i praktika obshchestvennogo razvitiya $=$ Theory and practice of social development, 2015, issue 21. Available at http://teoria-practica.ru/rus/files/arhiv_zhurnala/2015/21/ politics/baranov.pdf (accessed 14.04.2019). (In Russ.).

5. Demina A.V. Aktual'nost' izucheniya obrazovatel'nykh migratsiy [The relevance of the study of educational migration]. Molodoi Uchenyi = Young Scientist, 2018, no. 16 (202), pp. 267-269. Available at: https://moluch.ru/archive/202/49544 (accessed 18.03.2019). (In Russ.).

6. Drozhzhina D.S. Izuchenie adaptatsii inostrannykh studentov: diskussiya o metodologii [Exploring the adaptation of foreign students: a discussion on methodology]. Empirical Studies. Universitas. 2014, volume 1, no. 3, pp. 33-47. Available at: https://universitas.hse.ru/data/2014/01/10/1341074388/ адаптация \%20иностранных \%20студентов.pdf (accessed 10.02.2019). (In Russ.).

7. Immigratsiya kak vyzov natsional'noi bezopasnosti Rossii [Immigration as a challenge to the national security of Russia]. Doklad Instituta natsional'noi strategii = Report of the Institute of National Strategy. The team of authors under Mikhail Remizov's edition. Moscow, 2014, pp. 4-7. Available at http://www.instrategy.ru/pdf/276.pdf (accessed 10.02.2019). (In Russ.).

8. Integratsiya inokul'turnykh migrantov: perspektivy interkul'turalizma [Integration of migrants with different cultural background: prospects of interculturalismp]. Monograph. Executive editors: I.P. Tsapenko, I.V. Grishin. Moscow, IMEMO RAS4, 2018, pp. 204, 218-220. DOI: 10.20542/978-5-9535-0538-3 (In Russ.).

9. Kasyanov V.V., Shapovalov S.N. Mezhdunarodnaya migratsiya na territoriyu Krasnodarskogo kraya: sostoyanie i perspektivy [The international migration on the territory of Krasnodar krai: state and prospects]. Istoricheskaya $i$ sotsial'no-obrazovatel'naya mysl' = Historical and social-educational ideas, 2015, volume 7, no. 5/2, pp. 137-140. DOI: 10.17748/2075-9908-2015-7-5/2-137-140 (accessed 06.01.2019). (In Russ.).

10. Kashnitskiy I.S., Mkrtchyan N.V., Leshukov O.V. Mezhregional'naya migratsiya molodezhi v Rossii: kompleksnyi analiz demograficheskoi statistiki [Interregional Migration of Youths in Russia: A Comprehensive Analysis of Demographic Statistics]. Voprosy obrazovaniya = Educational Studies. Moscow, 2016, no. 3, pp. 169-196. Available at: https://vo.hse.ru/data/2016/09/19/1123199441/ Kashnitskiy.pdf (accessed 01.04.2019). (In Russ.).

11. Boucher F., Maclure J. Moving the debate forward: interculturalism's contribution to multiculturalism. Comparative Migration Studies, 2018, no. 6. DOI: 10.1186/s40878-018-0078-2

12. Dustmann C., Schonberg U., Stuhler J. The Impact of Immigration: Why Do Studies Reach Such Different Results? Journal of Economic Perspectives, 2016, vol. 30, no. 4, pp. 31-56.

13. Gimpelson V., Kapeliushnikov R. Age and Education in the Russian Labour Market Equation. IZA DP, 2017, no. 11126, p. 7.

Submitted 11.08.2019; revised 15.09.2019.

The author has read and approved the final manuscript. 


\begin{abstract}
About the author
Irina V. Rayushkina

Ph. D. (Philology), Deputy Director of International Affairs Department, Associate Professor (docent) of the Department of Applied Linguistics and Modern Information Technologies, Kuban State University, Krasnodar, interdep@mail.kubsu.ru
\end{abstract}

\title{
Роль университетов в формировании безопасной среды в условиях массовой миграции
}

\section{И. В. Раюшкина}

Статья посвящена проблемам сохранения национальной безопасности России в условиях массовой миграции с особым вниманием к образовательной миграции - иностранным студентам. В первой части статьи автор дает краткий обзор причин роста массовой миграции в России в целом и в Краснодарском крае в частности, обозначая внутренние и внешние риски и угрозы национальной безопасности страны. Во второй части на примере конкретного вуза - Кубанского государственного университета (КубГУ, Краснодар, Россия) - анализируются условия адаптации и интеграции иностранных студентов в иноязычную культуру на основе «диалога культур» как фундаментальных факторов формирования безопасной образовательной среды, предлагаются определенные подходы и пути ее формирования. Одним из принципиальных подходов к проблеме является так называемый «индивидуально-идентичный» подход к каждому иностранному студенту, основанный на личностно-психологических и формально-личностных отношениях между входящей и принимающей сторонами, что, в свою очередь, способствует возникновению и развитию диалога культур. Привлечение иностранных студентов к участию в общественной, социальной и культурной деятельности рассматривается автором как особый метод формирования безопасной образовательной среды в вузе, реализующий идею раскрытия внутреннего мира человека, его способностей, что ведет к устойчивому равновесию и гармонии личности. В качестве подтверждения достоверности данного тезиса автор приводит несколько мероприятий, проведенных в КубГУ с участием иностранных студентов. Также предлагается внедрить другие технологии, способствующие успешному диалогу культур и, как следствие, обеспечению безопасной среды в университете. В заключение автор подчеркивает важность, придаваемую университетам, которые призваны обеспечить безопасную и благоприятную образовательную среду для всех студентов, независимо от страны их происхождения.

Keywords: риски и угрозы массовой миграции, иностранные мигранты, трудовая миграция, мультикультурализм, интеркультурализм, образовательная миграция, Кубанский государственный университет, иностранные студенты, адаптация, общественная социокультурная интеграция, инокультурная 
среда, безопасная среда для образования, межэтнические конфликты, индивидуальный подход, диалог культур

Примечание: эта статья включает в себя отчет с тем же названием, который был представлен в форме выступления на международной научной конференции «Негосударственные субъекты и безопасность региона Евро-Средиземноморья", организованной сетью Жана Монне «Мир, Война и мир в вызовах европейской безопасности (державы)» и состоявшаяся 29-31 января в Университете Иордании (Центр стратегических исследований) в Аммане (в соответствии с Грантом Erasmus+ № 599962-EPP-1-2018-1-RU-EPРJMO-сеть).

Благодарности: автор выражает искреннюю признательность и благодарность руководителю проекта Кубанского государственного университетапрофессору кафедры публичной политики и публичного администрирования Елене Морозовой за приглашение к участию в проекте, профессору кафедры социологии Владимиру Петрову и профессору кафедры регионоведения и дипломатии КубГУ Юрию Смертину, а также профессору социологии доктору Маршалу Боткину (США) за советы, рекомендации и критические замечания, высказанные автору в процессе работы над данной статьей.

Для цитирования: Раюшкина И.В. Роль университетов в формировании безопасной среды в условиях массовой миграции. West - East. 2019, no. 12, pp. 118-130. DOI: 10.30914/2227-6874-2019-12-118-130

\section{Список литературы}

1. Аверьянов А.В. Миграционные процессы на юге России за последние 25 лет: динамика и основные направления // Проблемы национальной стратегии. 2015. № 6 (33). URL: https://riss.ru/images/pdf/journal/2015/6/07_pdf (дата обращения: 18.03.2019).

2. Авксентьев В.А., Гриценко Г.Д. Противоречивость этнополитических тенденций на Северном Кавказе: экспертные оценки // Гуманитарий юга России. 2018. № 3. URL: https://cyberleninka.ru/article/n/protivorechivost-etnopoliticheskih-tendentsiy-na-severnom-kavkazeekspertnye-otsenki (дата обращения: 02.04.2019).

3. Апажева С.С., Мамсиров А.Х., Цолоев Т.С. Северный Кавказ: современная этнополитическая ситуация и перспективы ее стабилизации // История: факты и символы. 2017. № 13. URL: $\quad$ http:/historic-journal.ru/2017/sovremennaya-etnopoliticheskaya-situaciya-na-severnom-kavkaze (дата обращения: 14.04.2019).

4. Баранов А.В. Этнополитические процессы в краснодарском краев контексте геополитических трансформаций // Теория и практика общественного развития. 2015. Вып. 21. URL: http://teoria-practica.ru/rus/files/arhiv_zhurnala/2015/21/politics/baranov.pdf (дата обращения: 14.04.2019).

5. Демина А.В. Актуальность изучения образовательных миграций // Молодой ученый. 2018. № 16. C. 267-269. URL: https://moluch.ru/archive/202/49544 (дата обращения: 18.03.2019).

6. Дрожжина Д.С. Изучение адаптации иностранных студентов: дискуссия о методологии // Эмпирические исследования. Universitas. 2014. Т. 1. № 3. С. 33-47. URL: https://universitas.hse.ru/data/ 2014/01/10/1341074388/адаптация\%20иностранных\%20студентов.pdf (дата обращения: 10.02.2019).

7. Иммиграция как вызов национальной безопасности России. Доклад Института национальной стратегии // под ред. М.В. Ремизова. Moscow, 2014. C. 4-7. URL: http://www.instrategy.ru/ pdf/276.pdf (дата обращения: 10.02.2019). 
8. Интеграция инокультурных мигрантов: перспективы интеркультуризма / под ред.: И.П. Цапенко, И.В. Гришин. М. : IMEMO RAS4, 2018. С. 204, 218-220. DOI: 10.20542/978-59535-0538-3

9. Касьянов В.В., Шаповалов С.Н. Международная миграция на территории Краснодарского края: состояние и перспективы // Историческая и социально-образовательная мысль. 2015. Т. 7. № 5/2. C. 137-140. DOI: 10.17748/2075-9908-2015-7-5/2-137-140 (дата обращения: 06.01.2019).

10. Кашницкий И.С., Мкртчян Н.В., Лешуков О.В. Межрегиональная миграция молодежи в России: комплексный анализ демографической статистики // Вопросы образования. М., 2016. № 3. C. 169-196. URL: https://vo.hse.ru/data/2016/09/19/1123199441/Kashnitskiy.pdf (дата обращения: 01.04.2019).

11. Boucher F., Maclure J. Moving the debate forward: interculturalism's contribution to multiculturalism // Comparative Migration Studies, 2018, no. 6. DOI: 10.1186/s40878-018-0078-2

12. Dustmann C., Schonberg U., Stuhler J. The Impact of Immigration: Why Do Studies Reach Such Different Results? // Journal of Economic Perspectives. 2016. V. 30. No. 4. P. 31-56.

13. Gimpelson V., Kapeliushnikov R. Age and Education in the Russian Labour Market Equation // IZA DP. 2017. № 11126. P. 7.

Статья поступила в редакцию 11.08.2019 г.; принята к публикации 15.09.2019 г. Автор прочитал и одобрил окончательный вариант рукописи.

\section{Об авторе}

\section{Раюшкина Ирина Владимировна}

кандидат филологических наук, доцент, доцент кафедры прикладной лингвистики и современных информационных технологий, заместитель директора Департамента по международным связям, Кубанский государственный университет, г. Краснодар, interdep@mail.kubsu.ru 